\title{
The Traditional Musical Instrument of West Sumatera As a-non Formal Education
}

\author{
Fris Okta Falma ${ }^{1)}$, Ambiyar ${ }^{2 *}$, Ishak Aziz $^{3)}$ \\ 1) Program Studi Doktor Ilmu Pendidikan Pascasarjana Universitas Negeri Padang
}

2) Universitas Negeri Padang

*Coresponding Author

Email : frisokta@gmail.com

\begin{abstract}
This study aims to identify and understand the types of traditional instrument from West Sumatra. The method used in this study uses a library method or approach (library research). Data obtained through observation and literature study. The results showed that the traditional instruments of West Sumatra are Talempong, Saluang, Pupuik Batang Padi, serunai, tambua and tansa. Minangkabau traditional musical instruments have various types and forms that usually used on certain occasions. The uniqueness of Minangkabau musical instruments can be seen from how to play it The people of West Sumatra still maintains traditional music because it is considered to function as a medium for non-formal education and cultural identity for the people of West Sumatra
\end{abstract}

Keywords: Traditional Musical Instrument, Non-Formal Education

\section{INTRODUCTION}

Art is an element of culture that develops in line with human development as a changer and connoisseur of art. Art can also be interpreted as a result of human work that has a value of beauty that can be done and enjoyed through several expressions such as sound, motion or other expressions. This is because art is a manifestation of the feelings that exist in oneself man. Art has many types ranging from dance, painting, drama, visual arts and music. Even art is very developed everywhere, both in foreign countries and even in Indonesia especially in West Sumatra.

West Sumatra is a province of Indonesia. On the west coast of the island of Sumatra, the province has an area of $42,012.89 \mathrm{~km} 2$, and it had a population of 4,846,909 at the 2010 Census[4] and 5,534,472 at the 2020 Census. The province includes the Mentawai Islands off the coast and borders the provinces of North Sumatra to the north, Riau and Jambi to the east, and Bengkulu to the southeast. West Sumatra is sub-divided into twelve regencies and seven cities. It has relatively more cities than other provinces outside of Java, although several of them are relatively low in population compared with cities elsewhere in Indonesia. Padang is the province's capital and largest city.

West Sumatra is home to the Minangkabau people, although the traditional Minangkabau region is actually wider than the province's boundaries, covering up to the southern region of North Sumatra, the western region of Riau, the western region of Jambi, the northern region of 
Bengkulu, and Negeri Sembilan in Malaysia. Another native ethnic group is Mentawai people, who inhabit the western islands of the same name.

However, West Sumatra is well known with the traditional music. Traditional Musical Instruments of West Sumatra is one of the provinces on the island of Sumatra, which has in the provincial capital of Padang. Music of Minang is a traditional and living genre of Indonesian music that grows and develops in the Minangkabau culture area. Music whose origins are related to Malay Music is generally played by musical instruments such as Talempong, Saluang, Minang rebab, Serunai, Tambourine, Aguang, Gandang, and Violin. Minang music is also played to accompany various dances such as the Pasambahan dance and the Piring dance.

Minangkabau traditional musical instruments have various types and forms that usually used on certain occasions. The uniqueness of Minangkabau musical instruments can be judging by how to play it. Not everyone can play a musical instrument Minangkabau tradition, except for people who have expertise in their fields and retain these skills. This musical instrument is also very pleasant to listen to even though it is combined with modern musical instruments today, so that traditional musical instruments Minangkabau will always be awake even though various modern musical instruments appear other.

To find out the existence, types and variety of Minangkabau traditional musical instruments very necessary an information or tracking system that can be used anytime only and useful when needed. Information is a collection of processed data and can know the intent and purpose of the content of the information submitted, so that information is very important for users who need it. Therefore, the management information is required to be able to create an information that is useful for the community in searching for information.

\section{RESEARCH METHODS}

The method used in this study uses a library method or approach (library research), Literature study or literature can be interpreted as a series of activities that regarding the methods of collecting library data, reading and recording and processing materials research (Zed, 2003:3).

In literature research, there are at least four main characteristics that the author need to pay attention to, among others: First, that the author or researcher is dealing directly with the text or numerical data, not with direct knowledge from the field. Second, library data is "ready to use" means that the researcher does not go directly to the field because the researcher is dealing directly with data sources in the library. Third, that library data is generally a source of secondary, in the sense that the researcher obtains material or data from second hands and not data original from the first data in the field. Fourth, that the condition of the library data is not limited by space and time (Zed, 2003:4-5).

Based on the foregoing, the data collection in the research This is done by reviewing and/or exploring several journals, books, and documents (either in the form of print or electronic) as well as other sources of data and/or information considered relevant to the research or study.

\section{RESULTS AND DISCUSSION}

Minangkabau music on its way across various generations and communities, there are living and develop well, challenge or follow the development of the times, but some have ended and extinct leaving a name without an heir. Such is the length of time that has passed with 
various dynamics, but there are not many notes related to history that we can guide for reading materials and references for next generation.

The traditional musical instrument of West Sumatra as we know it today include :

1. Saluang

Saluang is a traditional musical instrument from West Sumatra made from Bamboo Talang.Saluang has a diameter of about 3-4 cm, length $40-60 \mathrm{~cm}$ and only has 4 holes. Saluang traditional musical instrument is played by blowing.

The uniqueness of this is that the blower saluang saluang will be able to play Saluang nonstop from the beginning to the end of the song. This is possible because the blower saluang have Hangok Mampasalisiahan technique (aside breath) that breathing techniques in saluang blow. In Minang, saluang usually not only sounds themselves. Musical instrument made of reed seruas this, be my maid sang rhymes. Poem sung, usually contains satire, lamentation, advice, or a joke. Usually if Saluang in inflatable Without singing accompanied aimed at treatment and kebathinan. In the video above is shown between Pedendang and Plumbers Saluang with listeners / viewers no demarcation but unity in enjoying the Saluang and sound though. It symbolizes togetherness Nature Realm of democracy in Minangkabau in philosophy "Surang Duduak basampik Sampik, duduak Basamo balapang airy". Saluang legendary players named Idris Sutan Sati with Syamsimar singer. According Ediwar (2017) that a type of end-blown musical instrument withoutblock flutes used to accompany singing or resounding Minangkabau. Accompanied dendang consists of two types rumble each type of rumble entertainment and type dendang magis. Saluang darek is used to accompany entertainment rage, saluang sirompak historically ever used to accompany a melody with a mantra poem 'Using' women at the will of men, then turned into entertainment with pantunpantun poetry is entertaining. The striking difference is repertoire of songs on each type of musical instrument.

2. Talempong

Talempong is a traditional percussion instruments Minangkabau. Traditional musical instruments developed in the community of West Sumatra is made of brass, but some some are made of wood and stone. Traditional musical instrument is the same talempong same shape with a musical instrument bonang in gamelan in Java. Talempong circular with a diameter of 15 to 17.5 inches, the bottom holes while at the top there is a prominent roundabout five centimeters in diameter as a place to hit. Talempong has a different tone. The sound generated from a pair of wood struck on its surface. Talempong usually played to accompany the dance performances or reception, as typical Plate Dance, Dance Pasambahan, and Dance galombang. The term talempong can be interpreted as one of the types of traditional music in Minangkabau. The term talempong itself can also be interpreted as a percussion instrument with bronze and what is unique is the Minangkabau people too interpreted as 'resonant sound' resulting from wasp (hitting) an object.

3. Pupuik Batang Padi

Pupuik Batang Padi is a traditional musical instrument developed in the area of West Sumatra Agam. Traditional musical instruments Pupuik rice straw is indeed made of rice stem segments and jointed old. The process of making pupuik (crowbar) rice stem simple count. Old rice straw carefully broken near the base of his book. Fractions rod will form a kind of vocal cords is the source of the sound. If blown, the vocal cords are pitched wheezes. Although pupuik rice straw is only made of rice straw, but these tools become part of the entertainment of the people who brighten the lives of people of West Sumatra. Traditional musical instrument of West Sumatra can then be connected to the coil so that the palm leaves produced increasingly shrill voice and can be heard up to a distance of 2 kilometers. 


\section{Serunai}

Traditional flute is a musical instrument made from rice straw, wood or bamboo, buffalo horn or coconut leaves are played by blowing. Flute comes from the word Shenai which is a musical instrument that originated from the Valley of Kashmir in northern India Datara. and Serunai musical instruments are found equally in the province of of West Sumatra, especially in the highlands such as in the area of Agam, Tanah Datar and Fifty Cities, and also along the coast of of West Sumatra. Flute has a length of about $20 \mathrm{~cm}$, has 4 holes is $2.5 \mathrm{~cm}$. The function of these holes is to set the rhythm. Meanwhile, the tone of this instrument together with other modern instruments, ie pentatonic or do-re-mi-fa-sol. This tone is prevalent in traditional Minang musical instruments.

5. Tambua \& Tansa

Tambua a musical instrument from West Sumatra made of wood hollowed center, usually a length of $60-70 \mathrm{~cm}$ and $40-50 \mathrm{~cm}$ diameter circle and has a thickness of $1-1.5 \mathrm{~cm}$ circle. On both sides of his given animal skin (usually goat skin) which has been dried and fastened in such a way that ties the threads as it is made attractive.

This art tools used to symbolize joy and commonly used in the wedding ceremony, reception or special guests in order to show Batagak Gala Ceremony or Batagak Tower. Tambua struck simultaneously with a regular rhythm and movement is led by an art tool called "Tansa". Based on this Tansa rhythm was Tambua art tool is sounded. Tansa be a cauldron-shaped vessel with a diameter of 14 inches. made aluminum surface is covered thin skin, in the early development of the Tansa Tambua used deer skin, but in accordance with the times, deer skin has begun to not wear anymore, current Tansa wearing plastic mica / drum head. Tambua and Tansa played by a minimum of 4 players. Tansa Tambua game also accompanied ole other instruments such as Talempong, pupuik tanduak / sarunai and also pupuik rice stalks. With this tool, the sound will be more crowded Tambua Tansa.

\section{Non Formal Education}

The types of traditional Minangkabau music which is very commonly known by the wider community based on how to play it, for example: traditional music beat (percussion), traditional wind music; traditional stringed music, and music picking tradition. The community is an informal process that provides re-socialization of the system of values and norms prevailing in society. The presence of this community is the initial stage for a child to get further services, therefore the community is very important as a safe, comfortable and fun place for children. In improving this skill is a process by which children learn. The more often children learn, the skills they have indirectly increase and increase according to what they learn. The learning process in the traditional music of West Sumatra is fun and without any sense of compulsion, so that children feel comfortable and happy to know and learn traditional art music.

The implementation of traditional music education uses practical and theoretical methods, where practice and theory takes place simultaneously. In this course, the instructor puts more emphasis on practice because for music courses, if you use theory alone, you will have difficulty in receiving the material. The practical method used in the music course is that each student is faced with one type of traditional musical instrument.

\section{CONCLUSION}

Based on the explanation above, the writer concludes that West Sumatra is wellknown with the traditional music. Music of Minang is a traditional and living genre of Indonesian music that grows and develops in the Minangkabau culture area. Music whose origins are 
related to Malay Music is generally played by musical instruments such as Talempong, Saluang, Pupuik Batang Padi, serunai, tambua and tansa. Minangkabau traditional musical instruments have various types and forms that usually used on certain occasions. The uniqueness of Minangkabau musical instruments can be seen from how to play it.

Traditional music of West Sumatra is considered functioning as an entertainment and a medium for non-formal education, apart from being the cultural identity of the community in West Sumatra. Traditional music of West Sumatra shows the art, social, economic and cultural education. Until now the values which it contains have been indirectly transmitted by the local community through artistic activities.

\section{REFERENCES}

Arikunto S. Prosedur Penelitian Suatu Pendekatan Praktik Edisi Revisi V. Jakarta: Rineka Cipta. 2005.

Ediwar, dkk. Musik tradisional Minangkabau. Penerbit GRE. Magelang. 2017.

Elina Murniati, Darmansyah, "Kemasan Seni Pertunjukan Tradisional Sebagai Daya Tarik Wisata di Istana Pagaruyung Basa,” Panggung. jilid 28, 2018.

Hanefi Dkk. Talempong Minangkabau: Bahan Ajar Musik dan Tari. (Bandung: P4ST. 2004).

M. Alkaf, "Dance as a Cultural Symptom: A Study on the Existence of Folk Dance in Boyolali," Int. J. Indonesia. soc. Cult.. vol. 4, no. 2, pp. 125-138, 2012.

Merriam, A. P. The Anthropology of Music. Illinois: Northwestern University Press. 1964. Moldovan and V. Bocos-Bintintan, "The Necessity of Reconsidering the Concept of Nonformal Education," Procedia - Soc. Behav. Sci., vol. 209, pp. 337-343, 2015.

Morgan, A. An investigation into the learning environments associated with the band and music service worlds in Northern Ireland: A qualitative comparison of formal with non -formal learning. Unpublished PhD thesis, University of Ulster, Northern Ireland. 2000 